\title{
EVALUATION OF PRE-SERVICE TEACHERS' OPINIONS CONCERNING THE OBJECTIVES OF THE CITIZENSHIP EDUCATION
}

\author{
İLKÖĞRETIM ÖĞRETMEN ADAYLARININ VATANDAŞLIK EĞİTIMININ \\ AMAÇLARINA İLISSKİN GÖRÜŞLERINIIN DEĞERLENDİRILMESI
}

\author{
Ramazan ÖZBEK ${ }^{1}$ \\ Bahadır KÖKSALAN ${ }^{2}$
}

\section{$\ddot{O} z$}

Demokrasi, vatandaşlık ve hayat boyu öğrenme 21. yüzyılda uygulama ve düşüncede en önemli gündemdeki kavramlar arasındadır. Vatandaşlık eğitimi genel eğitimin ve demokrasi eğitiminin önemli bir parçasıdır. Vatandaşlık eğitimi yaygın olarak dört temel unsuru kapsayacak biçimde anlaşılmaktadır. Bunlar; a) politik katılım, b) eleştirel düşünme, c) toplumsal tutum ve d) değerler ile aktif katılımdır. Bu çalışmanın amacı, ilköğretim bölümü, sosyal bilgiler öğretmenliği anabilim dalında okuyan öğretmen adaylarının, İlköğretim Vatandaşlık ve Demokrasi Eğitimi Programı kapsamında vatandaşlık eğitimi amaçlarına ilişkin görüşlerinin değerlendirilmesidir. Bu çalışma nitel araştırma yöntemi olarak tasarlanmıştır. Çalışmaya 8. Yarıyılda öğrenim gören 20 öğretmen adayı amaçlı örnekleme yöntemi ile katılmışlardır. Veri toplama aracında öğretmen adaylarına cevaplandırmaları için "İlköğretim Vatandaşlık ve Demokrasi Eğitimi programı kapsamında vatandaşlık eğitiminin amaçlarına yönelik görüşleriniz nelerdir.” sorusu açık uçlu olarak yöneltilmiştir. Araştırmacılar tarafından veriler nitel araştırma tekniklerden içerik analizi kullanılarak çözümlenmiştir. Öğretmen adaylarının görüşleri amaçların teorik bilgiden ziyade uygulamaya, bilinç düzeylerinin geliştirilmesine, hem kendi toplumunun hem de diğer toplumların değer yargılarına saygılı olma, toplumsal kurallara uygun davranma, iyi ve aktif vatandaş olarak sorumluluklar almaya yönelik olması gerektiği vatandaşlık eğitiminin amaçları arasında ağırlıklı olarak ifade edilmiştir.

Anahtar Kelimeler: Vatandaşlık, vatandaşlık eğitimi, demokrasi ve insan hakları eğitimi.

\begin{abstract}
Citizenship, democracy and lifelong learning are among the most recurrent terms on account of practice and thinking in the 21 st century .Citizenship education is an important part of general education and democracy education. Citizenship education is commonly understood to include four main aspects such as (a) political literacy, (b) critical thinking, (c) social attitudes and (d) values and active participation. The purpose of this study is to evaluate the opinions of the pre-service teachers who study at the department of primary school education social sciences teaching, concerning the objectives of the citizenship education in the context with the curriculum of primary school citizenship and democracy education. This study was designed as a qualitative research method. 20 pre-service teachers in their $8^{\text {th }}$ academic term participated into the study through the intentional sampling method. The question as "What are your opinions concerning the objectives of the citizenship education in the context with the curriculum of primary school citizenship and democracy education?" was used as an open ended question in the data collection tool to ask pre-service teachers' opinions. The data were analyzed through the content analysis which is one of the qualitative techniques by the researchers. Based on the pre-service teachers' opinions regarding the objectives of the citizenship, it was mostly stated that the objectives should be applicable rather than theoretical, develop awareness level, be respectful for the values of both ones' society and others, act according to social rules, undertake responsibilities as a good and active citizen.
\end{abstract}

Key Words: Citizenship, citizenship education, democracy and human rights education.

1 İnönü Üniversitesi, Eğitim Fakültesi, EBB, ramazan.ozbek@inonu.edu.tr

2 İnönü Üniversitesi, Eğitim Fakültesi, bahadir.koksalan@inonu.edu.tr 


\section{INTRODUCTION}

The most important problems people encounter throughout their lives nowadays are the offered means to be able to benefit from the fundamental rights in universal standards as a person, responsibilities and sanctions a person experiences in his/her environment apart from compliance problems. Some traits such as mass communication mediums, press, tourism, immigration, working opportunities make the issue more important. As Wood (2012:78) states that increased globalization in the world, increased importance of information and mass communication technologies and increased international tourism, international marketing and monetary systems, multinational corporations and international working opportunities have broken traditional barriers. One of the most important determinants of the democratic life is human rights and citizenship applications in every country. It seems that these two traits determine whether country administration is democratic or not.

Democracy, Citizenship and Human Rights concepts are used in many places together. The ones' existence depends on the others' existence and efficiency and they are generally dealt in the educational curricula together. Educational understanding and application in Education for Democracy, Citizenship and Human Rights in every country show differences to some or large extend (EACEA, 2012: 17). The differences between a democratic administration and a totalitarian one stem from these application types. Traditional administration approaches, interest groups' presses, staking countries' claims on each other, religious and sectarian understanding and applications affect the education for democracy, citizenship and human rights radically.

Citizenship along with civic concept is defined as an identity which is determined according to ones' family nationality and to a place where a person is born or to the law indicating the conditions to be a citizen and states that a person belongs to which state or nationality (Demir et al., 1992: 372). According to Aybay (2000: 180), citizenship is generally defined as a legal bond which attributes a person to a state.

Citizenship education can be defined as a process of activities which enables the young to prepare their responsibilities and roles completely (Devies, 2000: 5).

The qualities of a citizenship are categorized in a variety of ways. However, in general, those characteristics are expected in those who have a citizen consciousness in democratically developed countries:

- A responsible citizen takes part in his/her country ruling indirectly being a member of non-governmental organizations and using the right to elect and be elected and obeys the laws and rules which make people live a comfortable and peaceful life.

- He/she knows that doing one's military service and tolling are a citizen's duties.

Nowadays, "democratic citizen" and "active citizenship" concepts come into prominence instead of citizen concept. One of the reasons to be preferred those concepts is that citizens are given new duties to protect and develop democracy and human rights. A democratic citizen is supposed to be a participant in every field, active, equitable, respectful for rights and freedoms and internalize democratic behavior types in addition to the listed characteristics above. He/ she has some characteristics such as being sensitive to environment, being respectful to rights and liberties, being responsible and so forth (MEB, 2012: 41). Active citizenship requires to be active not passive to handle democratic inadequacies. That is, it is supposed to undertake new responsibilities for citizens to participate into decisions, activities and use rights and freedom. In the context with the citizenship education, it is aimed that students have the necessary knowledge, skills and values to compose a democratic society, have the ability to evaluate issues critically and 
express their ideas, be respectful for others' ideas, have a culture to live together peacefully, be sensitive to his/her society, be an individual that can take action for the sake of the goodness of his/her society. In this way, when students learn their rights, responsibilities and responsibilities, they also learn laws, equality, justice, non-discrimination and democracy. Democratic citizenship education supports to be respectful for different religions, cultures, beliefs and cast of mind, thereby understanding and sharing a variety of values of ones' society (MEB, TTKB, 2010: 4).

The citizenship education in Turkish education system in a planned way starts with Tanzimat Reform Era. Giving importance to the citizenship education to reinforce the bond between the state and its citizens was a part of the innovation movement in this period. To raise individuals who know their citizenship responsibilities and love their counties in the Republic period were among the general objectives of Turkish national education. In our country, education for human rights and democracy were given as courses such as Civics, Social Sciences, Citizenship Knowledge, Education for Citizenship and Human Rights in the curriculum (MEB, TTKB, 2010: 4).

Education for Citizenship and Democracy in the $8^{\text {th }}$ grade classes in the primary education was given as an elective course for one hour in a week in 2010-2011 academic periods. Education for Human Rights, Citizenship and Democracy" was given as a compulsory course for two hours in a week in the $4^{\text {th }}$ grade classes in 2012-2013 academic periods. And now, Education for Citizenship and Democracy is offered to the students in the $8^{\text {th }}$ grade classes for one hour in a week in the curriculum. The course consists of the chapters such as "Each Person is Valuable, Democracy Culture, Our Right and Freedoms, Our Duties and Responsibilities".

The necessity of these changes in a short time can be argued. However, it is obvious that this case has affected the continuity of the course in a negative way.

The literature review revealed that there are three visions of "citizenship" which are particularly helpful: the personally responsible citizen; the participatorycitizen; and the justice-oriented citizen (Westheimer\&Kahne, 2004).

Table 1: Kinds of Citizens

\begin{tabular}{|c|c|c|c|}
\hline & $\begin{array}{c}\text { Personally } \\
\text { Responsible Citizen }\end{array}$ & Participatory Citizen & $\begin{array}{l}\text { Justice-oriented } \\
\text { Citizen }\end{array}$ \\
\hline 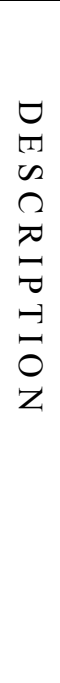 & $\begin{array}{l}\text { - Acts responsibly in } \\
\text { his/her community } \\
\text { - Works and pays } \\
\text { taxes } \\
\text { - Obeys laws } \\
\text { - Recycles, gives } \\
\text { blood } \\
\text { - Volunteers to give a } \\
\text { hand in times of } \\
\text { crisis }\end{array}$ & $\begin{array}{l}\text { - is an active member of } \\
\text { community, organizations } \\
\text { and/or improvement } \\
\text { efforts } \\
\text { - Organizes community } \\
\text { efforts to care for those in } \\
\text { need, promote economic } \\
\text { development, or clean up } \\
\text { environment } \\
\text { - Knows how government } \\
\text { agencies work } \\
\text { - Knows strategies for } \\
\text { accomplishing collective } \\
\text { tasks }\end{array}$ & $\begin{array}{l}\text { - Critically assesses social, } \\
\text { political, and economic } \\
\text { structures to see beyond } \\
\text { surface causes } \\
\text { - Seeks out and addresses } \\
\text { areas of injustice } \\
\text { - Knows about social } \\
\text { movements and how to } \\
\text { effect systemic change }\end{array}$ \\
\hline
\end{tabular}




\begin{tabular}{|c|c|c|c|c|}
\hline & $\begin{array}{l}\infty \\
2 \\
3 \\
0 \\
0 \\
\pi\end{array}$ & $\begin{array}{l}\text { Contributes food to a } \\
\text { food drive }\end{array}$ & $\begin{array}{l}\text { Helps to organize a food } \\
\text { drive }\end{array}$ & $\begin{array}{l}\text { Explores why people are } \\
\text { hungry and acts to solve } \\
\text { root causes }\end{array}$ \\
\hline 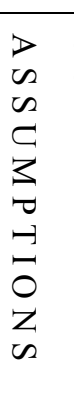 & $\begin{array}{l}2 \\
2 \\
\pi \\
\pi\end{array}$ & $\begin{array}{l}\text { To solve social } \\
\text { problems and improve } \\
\text { society, citizens must } \\
\text { have good character; } \\
\text { they must be honest, } \\
\text { responsible, and law- } \\
\text { abiding members of } \\
\text { the community }\end{array}$ & $\begin{array}{l}\text { To solve social problems } \\
\text { and improve society, } \\
\text { citizens must actively } \\
\text { participate and take } \\
\text { leadership positions } \\
\text { within } \\
\text { systems and community } \\
\text { structures }\end{array}$ & $\begin{array}{l}\text { To solve social problems } \\
\text { and improve society, } \\
\text { citizens must question and } \\
\text { change } \\
\text { systems and structures } \\
\text { when they reproduce } \\
\text { patterns of injustice over } \\
\text { time }\end{array}$ \\
\hline
\end{tabular}

In the studies fourmain categories of objectives for citizenship education have been stressed (Eurydice, 2005: 23). In this present study, the objectives have been further broken down, resulting in four main categories: concepts);

- Developing political literacy (knowledge of basic facts and understanding of key

- Acquiring critical thinking and analytical skills;

- Developing certain values, attitudes and behaviours (sense of respect, tolerance, solidarity, etc.);

- Encouraging active participation and engagement at school and community levels.

The first objective - the development of political literacy - often includes learning about issues such as social, political and civic institutions; human rights; national constitutions; citizens' rights and responsibilities; social issues; recognition of the cultural and historical heritage as well as the cultural and linguistic diversity of society. The second objective complements the first as critical thinking is crucial to developing political literacy since it allows young people to analyse and evaluate information on social and political issues. The third objective relates to the values, attitudes and behaviours students should acquire through citizenship education at school. Although not an exhaustive list, this objective may comprise, for instance, learning about respect and mutual understanding, social and moral responsibilities, and developing a spirit of solidarity with others. The last objective which requires students to actively participate in their community enables them to put into practice the knowledge and skills they have learned, as well as the values and attitudes they have acquired through their learning in connection with the first three objectives. These four objectives also reflect the fact that to be successful, citizenship education, when taught and learnt at school, must go beyond 'narrow, formal approaches which are largely content-led and knowledge-based. The primary aim is not only to inform, but also to use that information to help students to understand and to enhance their capacity to participate' (EACEA P9 Eurydice, 2012: 27)

The general objectives of the citizenship education in the context with the Education for Citizenship and Democracy (TTKB, 2010: 6) by Ministry of National Education (MONE) as follows:

Through this curriculum, it is aimed that students should; 
- Contribute to comprising a fair and democratic society as an individual who is free, independent, tolerant, confident and in favor of peace,

- Internalize the importance of protecting and developing the shared values,

- Fulfill his / her responsibilities using his/ her basic right and freedom as a citizen of Turkish Republic,

- Play a role in developing and strengthening the social life as an active, responsible and democratic citizen,

- Contribute to solving personal and social problems believing in the importance of democratic participation and democratic life,

- Internalize democracy as a life style developing democratic attitudes and behaviors as an individual who has a consciousness of democracy,

- Contribute to comprising a democratic Turkish Republic State internalizing the importance of Atatürk's principles and revolution,

- Show sensitivity to the issue related with his / her country and the world being aware of a part of humanity.

Curriculum consists of aims, content, method, sources and evaluation processes. In this study, the objectives of the citizenship education in the context with the education for citizenship and democracy in the primary education were evaluated according to the preservice teachers' opinions in the Social Sciences Department in the Primary Education.

\section{II.METHOD}

\subsection{Research Design}

This study was designed as a phenomenology research. It has been seen that there are serious criticisms concerning the quality and applicability of the aims of "Education for Citizenship and Democracy" course in the curriculum in the primary education based on the study carried out in this field. The fact that the quality of democracy education has been questioned is considered as significant nowadays in which the democratic life style has gained importance. Phenomenological researches, one of the qualitative research types, are the researches which try to reveal individuals' experiences, perceptions and attributed meanings to a phenomenology (Yıldırım \& Şimşek, 2006).

\subsection{Study Group}

This study was carried out in 2013-2014 spring academic period at Inonu University. 25 pre-service teachers in the Social Sciences Department in the Primary Education of the Education Faculty of the university participated into the study. 11 male and 14 female preservice teachers were selected through the purposeful sampling method. The pre-service teachers were informed about the aims and scope of the study and the basic principles about filling out the forms before the application.

\subsection{Development of Data Collection Tool}

The written form which requires student to find and write answers by thinking on his /her own was used. While it was being created, it was consulted to an expert. The actual form was created after the criticisms. The pre-service teachers were asked "what are your opinions concerning the objectives of the citizenship education in the context with the education for citizenship and democracy in the primary education?" as an open ended question in the data collection tool.

\subsection{Analysis of Data}


The data were analyzed through the content analysis which is one of the qualitative techniques by the researchers. Strauss and Cobin(taken by Yașar, 2014) mention about three types of coding. 1. Coding made according to the determined concepts beforehand 2. Coding made according to concepts which are derived from data. 3. Coding made in a general framework. In this study, coding was made based on the concepts which were derived from the data. The answers the pre-service gave to the questions were grouped in terms of their similarities. The ideas which have the same meaning were commented having been taken into account their frequency values. An expert's analysis was considered to increase the reliability of the study and the common points were determined.

\section{FINDINGS AND COMMENTS}

When the data in the table were examined, it was seen that there were some similarities about some issues concerning the pre-service teachers' opinions. The pre-service teachers' opinions were set down in section of introduction on four main objectives.

Table 2: The Pre-service Teachers' Opinions Concerning the Developing political literacy (Knowledge of Basic Facts and Understanding of Key Concepts)

\begin{tabular}{|c|c|c|c|c|}
\hline Categories & $\begin{array}{l}\text { The Objectives of the Citizenship } \\
\text { Education; }\end{array}$ & $\begin{array}{c}\text { Pre-service } \\
\text { teacher }(\mathrm{N}=25)\end{array}$ & $\mathbf{F}$ & $\%$ \\
\hline \multirow{4}{*}{$\begin{array}{l}\text { Developing } \\
\text { political } \\
\text { literacy } \\
\text { (knowledge of } \\
\text { basic facts and } \\
\text { understanding } \\
\text { of key } \\
\text { concepts) }\end{array}$} & $\begin{array}{l}\text { 1. They should be concerned with } \\
\text { how and under what conditions } \\
\text { people use their rights. }\end{array}$ & $\begin{array}{l}\text { P1,P4,P5,P9,P10, } \\
\text { P11,P12,P13,P19 } \\
\text {,P22,P23,P25 }\end{array}$ & 12 & 48 \\
\hline & $\begin{array}{l}\text { 2. They should be concerned with } \\
\text { acquiring awareness for individual } \\
\text { rights and responsibilities. }\end{array}$ & $\begin{array}{l}\text { P1,P4,P5,P8,P9,P } \\
\text { 10,P13,P17,P19, } \\
\text { P22,P23,P25 }\end{array}$ & 12 & 48 \\
\hline & $\begin{array}{l}\text { 22. They should be concerned with } \\
\text { teaching how to benefit from } \\
\text { political rights. }\end{array}$ & P8,P17, & 2 & 8 \\
\hline & $\begin{array}{l}\text { 6. They should be concerned with } \\
\text { acquiring not only knowledge but } \\
\text { also values and behaviors. }\end{array}$ & P3,P17 & 2 & 8 \\
\hline
\end{tabular}

Table 1 represents the data considering pre-service teachers' views on "developing political literacy" which is among the objectives of citizenship education. Among these objectives, While 12 pre-service teachers (48\%) claimed that the expression as "They should be concerned with how and under what conditions people use their rights" should be added within the objectives of citizenship education, other 12 pre-service teachers (48\%) stated that the expression of "They should be concerned with acquiring awareness for individual rights and responsibilities" must be added. These findings revealed that the pre-service teachers mostly signified using the duties and rights of citizenship, terms of use and acquisition of awareness quality. When this situation was compared with the results of other studies (Özmen, 2011; Başaran, 2007), the present result of the study was seen to be proper. Moreover, on account of developing political literacy, two of pre-service teachers ( $8 \%$ ) agree 
the items of "They should be concerned with teaching how to benefit from political rights" and "They should be concerned with acquiring not only knowledge but also values and behaviours". It can be concluded from these findings that citizenship education is mostly theoretical with regard to objectives and thus it should be developed in terms of applications.

Democratic life means that individuals living in a country should know even more importantly how to apply the information to every stage of their lives for their citizenship duties which are the basis of democracy in addition to knowing their citizenship duties. Otherwise it will not comply with the essence of democratic system and of life.

Table 3: The Pre-service Teachers' Opinions concerning the acquisition of critical thinking and analytical skills

\begin{tabular}{|c|c|c|c|c|}
\hline Categories & $\begin{array}{l}\text { The Objectives of the Citizenship } \\
\text { Education; }\end{array}$ & $\begin{array}{l}\text { Pre-service } \\
\text { teacher }(\mathrm{N}=25)\end{array}$ & & $\%$ \\
\hline \multirow{3}{*}{$\begin{array}{l}\text { Acquisition of } \\
\text { critical thinking } \\
\text { and } \\
\text { skills }\end{array}$} & $\begin{array}{l}\text { 19. They should be concerned with } \\
\text { understanding other societies' values and } \\
\text { being respectful for them. }\end{array}$ & $\begin{array}{l}\text { P1,P2,P8,P13,P15, } \\
\text { P17,P21 }\end{array}$ & 7 & 28 \\
\hline & $\begin{array}{l}20 . \text { They should be concerned with } \\
\text { raising individuals who use science and } \\
\text { technology appropriately. }\end{array}$ & P8,P19 & 2 & 8 \\
\hline & $\begin{array}{l}21 . \text { They should be concerned with } \\
\text { raising individuals who are honest and } \\
\text { fair. }\end{array}$ & P3,P16 & 2 & 8 \\
\hline
\end{tabular}

The data concerning the pre-service teachers' opinions on objectives of citizenship education related to "The acquiring critical thinking and analytical skills" was presented in Table 3. At this point Moore and Parker (2008) stated that critical analysis is the careful, deliberation of whether you should accept or reject judgement about a claim and the degree of confidence with which you do so (cited in Campbell, 2008). In the present study, when the data analysis was concerned, it was seen that seven pre-service teachers $(28 \%)$ focused on the item related to objectives of citizenship as "They should be concerned with understanding other societies' values and being respectful for them", the two $(8 \%)$ paid attention to the item as "They should be concerned with raising individuals who use science and technology appropriately" and the other two (8\%) considered the item as "They should be concerned with raising individuals who are honest and fair". In many other academic researches (Güven, Tertemiz and Bulut, 2009; Toraman, 2012), it was recognized that the teachers and preservice teachers asserted similar opinions as the findings in the present study.

One of the general objectives of education is to develop a balanced and healthy character physically, mentally, morally, spiritually and emotionally; a personality having an independent and scientific thinking power, a broad worldview; to train a constructive, creative and productive individual respecting human rights, appreciating personality and enterprise, feeling responsibility towards society (MEB, 2011, m.2). In general sense, one of the important objectives of education as well as citizenship education is that individuals should respect to the values of the other societies as well as to their own. In this context, the acquisition of properties such as critical thinking, analytical thinking, being fair and respectful to the values of other societies is of vital value. 
Table 4: The pre-service teachers' opinions concerning the developing certain values, attitudes and behaviors (sense of respect, tolerance, solidarity, etc.)

\begin{tabular}{|c|c|c|c|c|}
\hline Categories & $\begin{array}{l}\text { The Objectives of the Citizenship } \\
\text { Education; }\end{array}$ & $\begin{array}{l}\text { Pre-service } \\
\text { teacher }(\mathrm{N}=25)\end{array}$ & $\mathbf{F}$ & $\%$ \\
\hline \multirow{6}{*}{$\begin{array}{l}\text { The developing } \\
\text { certain values, } \\
\text { attitudes and } \\
\text { behaviors (sense } \\
\text { of respect, } \\
\text { tolerance, } \\
\text { solidarity, etc.) }\end{array}$} & $\begin{array}{l}\text { 3. They should be concerned with } \\
\text { internalizing social values. }\end{array}$ & $\begin{array}{l}\text { P2,P3,P4,P8,P15,P } \\
\text { 18,P19,P21 }\end{array}$ & 8 & 32 \\
\hline & $\begin{array}{l}\text { 5. They should be concerned with raising } \\
\text { individuals who act according to social } \\
\text { rules. }\end{array}$ & $\begin{array}{l}\text { P2,P8,P9.P13,P15, } \\
\text { P17,P24 }\end{array}$ & 7 & 28 \\
\hline & $\begin{array}{l}\text { 14. They should be concerned with } \\
\text { raising individuals who can adapt to } \\
\text { changing conditions. }\end{array}$ & P7,P21 & 2 & 8 \\
\hline & $\begin{array}{l}\text { 15. They should include the } \\
\text { characteristics the democrat citizens are } \\
\text { supposed to have. }\end{array}$ & P8,P9,P24 & 3 & 12 \\
\hline & $\begin{array}{l}\text { 16. They should be concerned with } \\
\text { acquiring attitudes, value and behaviors to } \\
\text { be able to answer social problems. }\end{array}$ & P7,P8,P23 & 3 & 12 \\
\hline & $\begin{array}{l}\text { 17. They should be concerned with } \\
\text { acquiring knowledge, skills and values to } \\
\text { understand the relationship between } \\
\text { person and state. }\end{array}$ & P10,P25 & 2 & 8 \\
\hline
\end{tabular}

In Table 4, the views of pre-service teachers related to the objectives of citizenship as "The developing certain values, attitudes and behaviours (sense of respect, tolerance, solidarity,etc.)" was examined. In this respect, it is known that there are four goals of school in general. The first one is to develop students' critical thinking skills and communication capacities with the help of using language effectively. The second goal of the school is to make them learn through experiences that are common and unique to all mankind, based on a mandatory program in the world which is globally interdependent on each other and where they live themselves and live the heritage of humanity. The third one is to prepare individuals to business life and to further education level and to ensure the development of their interests and abilities. The last goal is to make all students gain social and citizenship responsibilities through school and community service (Boyar, 1983: 67; cited in Aypay, 2008: 12).

It was noticed that pre-service-teachers are focused mainly on these four goals. When Table 4 was examined, eight pre-service teachers (38\%) were seen to express that "They should be concerned with internalizing social values" while seven $(28 \%)$ claimed that "They should be concerned with raising individuals who act according to social rules." Moreover, among the other opinions, while two pre-service teachers $(8 \%)$ agreed the item that "They should be concerned with raising individuals who can adapt to changing conditions", three (12\%) expressed their opinions towards the item of "They should include the characteristics the democrat citizens are supposed to have". Finally, three pre-service teachers' $(12 \%)$ opinions on "They should be concerned with acquiring attitudes, value and behaviors to be able to answer social problems" and the two ones' (8\%) on "They should be concerned with 
acquiring knowledge, skills and values to understand the relationship between person and state" were striking.

From these findings, it can be asserted that in addition to positive interaction relations, the effects of fanatical ideas group make it more important to attain the goals in this period in which there is an increase in inter-communal relations. Togetherness, harmony and respect for diversity and solidarity are indispensable elements human nature in this age. Now almost no society has the power to live away from other communities. The solution is common values such as harmony, respect, adaptation and cooperation.

Table 5: The pre-service teachers' opinions related to the encouragement of active participation and engagement at school and community levels.

\begin{tabular}{|c|c|c|c|c|}
\hline Categories & $\begin{array}{l}\text { The Objectives of the Citizenship } \\
\text { Education; }\end{array}$ & $\begin{array}{l}\text { Pre-service } \\
\text { teacher }(\mathrm{N}=25)\end{array}$ & $\mathbf{F}$ & $\%$ \\
\hline \multirow{8}{*}{$\begin{array}{l}\text { Encouragement } \\
\text { of active } \\
\text { participation and } \\
\text { engagement at } \\
\text { school and } \\
\text { community }\end{array}$} & $\begin{array}{l}\text { 4. They should be concerned with raising } \\
\text { individuals who are beneficial to society. }\end{array}$ & P2,P21 & 2 & 8 \\
\hline & $\begin{array}{l}\text { 7. They should be concerned with raising } \\
\text { individuals who will be involved in } \\
\text { developing their states. }\end{array}$ & P3,P5,P12,P19 & 4 & 16 \\
\hline & $\begin{array}{l}\text { 8. They should be concerned with } \\
\text { conveying a feeling to volunteer to } \\
\text { undertake responsibilities in communal } \\
\text { and social duties. }\end{array}$ & $\begin{array}{l}\text { P3,P4,P5,P7,P9,P } \\
13, P 13, P 18, P 24\end{array}$ & 9 & 36 \\
\hline & $\begin{array}{l}\text { 9. They should be concerned with raising } \\
\text { individuals who accept to obey to state } \\
\text { authority. }\end{array}$ & P5,P13 & & \\
\hline & $\begin{array}{l}10 \text {. They should be concerned with } \\
\text { raising good citizens who love their } \\
\text { homeland and nations. }\end{array}$ & $\begin{array}{l}\text { P5,P6.P7,P9,P10, } \\
\text { P11,P12,P13,P15, } \\
\text { P17,P19,P22 }\end{array}$ & 12 & 48 \\
\hline & $\begin{array}{l}11 . \text { They should be concerned with } \\
\text { raising citizens who are active and } \\
\text { efficient. }\end{array}$ & P7,P13,P19,P24 & 4 & 6 \\
\hline & $\begin{array}{l}\text { 12. They should be concerned with } \\
\text { raising individuals who not only know but } \\
\text { also put into practice what they know. }\end{array}$ & P3,P11,P14,P22 & 4 & 16 \\
\hline & $\begin{array}{l}\text { 13. They should be concerned with } \\
\text { getting family and other institutes to be } \\
\text { involved in the process. }\end{array}$ & P7,P25 & 2 & 8 \\
\hline
\end{tabular}

In the last Table of the study, pre-service teachers were appeared to put forward the idea within the scope of citizenship education that "The encouraging active participation and engagement at school and community levels". From the data analysis, most of the pre-service teachers stated that they agree the item of "They should be concerned with raising good citizens who love their homeland and nations" $(\mathrm{F}=12 ; \% 48)$. Similarly, nine pre-service 
teachers (36\%) signified that they agree the item as "They should be concerned with conveying a feeling to volunteer to undertake responsibilities in communal and social duties". The other items accepted in certain levels by pre-service teachers can be arranged as "They should be concerned with raising individuals who will be involved in developing their states.", "They should be concerned with raising citizens who are active and efficient.", "They should be concerned with raising individuals who not only know but also put into practice what they know", "They should be concerned with raising citizens who are active and efficient", "They should be concerned with raising individuals who not only know but also put into practice what they know.", "They should be concerned with raising individuals who are beneficial to society.", "They should be concerned with raising individuals who accept to obey to state authority" and "They should be concerned with getting family and other institutes to be involved in the process".

When the study findings were taken into consideration, there were seen to be some definitions showing major differences in the frame of citizenship terms however the common points emphasized were stated as the duty of tax, of obeying laws, of taking part in the country defence and of election. The political system of the country is also the most significant factor in the implementation of citizenship duty. However in general, "rights" in democratic countries, "responsibilities-tasks" in totalitarian countries come to the forefront. But the fact that responsibilities in addition to the rights determine the citizenship and applications is a fact not to be underestimated.

The core of democracy is given rights to individuals and citizenship relationships. In fact, these two concepts are complementary to each other. It can be said that the one's existence depends on the others' existence. A person must fulfill his / her responsibilities while he /she can use his/ her rights in context of school and class, family, environment and media relationships.

Radically differences between the social, cultural and economic structures of countries and their citizenship characteristics are seen in studies which are made in domestic and abroad. Nowadays, the development level of countries is seen to be related with not only their economies but also their citizens' having rights to be able to live in a "qualified" way and the citizenship applications in one country. The fact that individuals prepare for their future life starting from their families and continuing at educational institutes, are happy and their countries encounter less problems will be possible with a serious democracy education. This is not possible with a common understanding and application.

\section{RESULTS AND SUGGESTIONS}

The mostly stated opinions of the social sciences pre-service teachers in the primary education concerning the objectives of the citizenship education in the context with the "Education for Citizenship and Democracy" given for one hour in a week in the $8^{\text {th }}$ grade are given below.

- They should be concerned with how and under what conditions people use their rights.

- They should be concerned with acquiring awareness for individual rights and responsibilities.

- They should be concerned with internalizing social values.

- They should be concerned with raising individuals who act according to social rules.

- They should be concerned with conveying a feeling to volunteer to undertake responsibilities in communal and social duties. 
- They should be concerned with raising good citizens who love their homeland and nations.

- They should be concerned with understanding other societies' values and being respectful for them.

Democracy education in the curriculum should be given more serious place in planning and application. The whole process starting from determining objectives to evaluation criteria should be reviewed and necessary changes should be put into practice immediately. The level of fulfillment of objectives of curriculum, effectiveness of the process, their appropriateness to real life, program development for citizenship education, curriculum programs, and outcomes of the curriculum can be thought to be studied.

\section{REFERENCES}

Aybay, R. (2000). İnsan hakları açısından vatandaşlık (uyrukluk), insan hakları. İstanbul: Yapı Kredi Yayıncılık.

Aypay, A. (2008). Eğitimde amaçlar ve toplumsal sistem. Eskişehir: Anadolu Üniversitesi Açıköğretim Fakültesi Yayınları.

Başaran, T. (2007). İlköğretim okullarında vatandaşlık ve insan hakları eğitimi programının uygulanışına ilişkin sosyal bilgiler öğretmenlerinin görüşleri. (Yayımlanmamış yüksek lisans tezi), Trakya Üniversitesi, Sosyal Bilimler Enstitüsü, Edirne. RetrievedJanuary 29, 2015 from http://193.255.140.18/Tez/0059107/METIN.pdf

Bronwyn E. W. (2012). Scales of activecitizenship: New Zealandteacherse diverse perceptions and practices. International Journal of ProgressiveEducation, 8(3), ppp????

Campbell, S. (2008). Studyadvice service criticalthinking. RetrievedJanuary 29, 2015 from http://www2.hull.ac.uk/student/pdf/Critical\%20thinking\%20(S\%20campbell\%20new\%2 0version)2.pdf

Davies, L. (2000). Citizenship education and human rights education-keyconceptsanddebates. The British Council Design Department, University of Birmingham.

Demir, Ö., \& Acar, M. (1992). Sosyal bilimler sözlüğü. İstanbul: Ağaç Yayıncılık.

Education, Audiovisualand Culture ExecutiveAgency (2012). Citizenship education in Europe, P.13. Retrieved May 17, 2014 from http://eacea.ec.europa.eu/education/eurydice

Güven S., Tertemiz, N. \& Bulut, P. (2009). Vatandaşlık ve vatandaşlık eğitimine yönelik öğretmen görüşleri. RetrievedJanuary $30, \quad 2015$ from http://www.eab.org.tr/eab/2009/pdf/181.pdf

MEB, TTKB. (tarihsiz). İlkogretim okullari haftalik ders çizelgesi. Retrieved May 16, 2014 from http://ttkb.meb.gov.tr/www/ilkogretim-okullari-haftalik-ders-cizelgesi/icerik/13

MEB, TTKB. (2010). İlköğretim vatandaşlık ve demokrasi eğitimi dersi 8.sınıf öğretim program1. Ankara.

Özmen, C. (2011). Sosyal Bilgiler Eğitiminde Vatandaşlık Aktarımı Yaklaşımına İlişkin Öğretmen Görüşleri. Mustafa Kemal University Journal of Social Sciences Institute, $8(15), 435-455$. 
Toraman Ç. (2012). İlköğretim 8. sınıf vatandaşlık ve demokrasi eğitimi ders programının (2010) değerlendirilmesi. (Yayımlanmamış yüksek lisans tezi), Ankara Üniversitesi Eğitim Bilimleri Enstitüsü, Ankara.

Westheimer J. \&Kahne J. (2004). Educatingthe "good" citizen: political choices and pedagogical goals. PSOnline. RetrievedJanuary 29, 2015 from http://www.mills.edu/academics/faculty/educ/jkahne/ps_educating_the_good_citizen.pdf

Yıldırım, A. \& Şimşek, H. (2013). Sosyal bilimlerde nitel araştırma yöntemleri. Genişletilmiş 9. Baskı. Ankara: Seçkin Yayıncılık. 